\title{
KONTRIBUSI LABORATORIUM KIMIA DAN SIKAP SISWA TERHADAP PEMANFAATAN LABORATORIUM TERHADAP KETERAMPILAN BERPIKIR KRITIS DAN KREATIF
}

\author{
NOVRITA MULYA ROSA \\ muly4ros4@gmail.com \\ FATWA PATIMAH NURSA'ADAH \\ Universitas Indraprasta PGRI Jakarta \\ Jl. Nangka 58. Tanjung Barat (TB Simatupang), Jagakarsa, Jakarta Selatan
}

\begin{abstract}
Abstrak. Tujuan dari penelitian adalah untuk menganalisis kontribusi laboratorium kimia dan sikap siswa terhadap pemanfaatan laboratorium kimia terhadap keterampilan berpikir kritis dan kreatif. Subjek penelitian siswa kelas XI SMAN 66 di kecamatan Cilandak, Jakarta Selatan. Pemilihan kelas sampel menggunakan teknik random sampling. Analisa data penelitian menggunakan teknik MANOVA. Dari hasil penelitian disimpulkan bahwa (1) ada pengaruh kontribusi laboratorium terhadap keterampilan berpikir kritis dan keterampilan berpikir kreatif kimia; (2) ada pengaruh sikap terhadap pemanfaatan laboratorim terhadap keterampilan berpikir kritis dan keterampilan berpikir kreatif kimia; (3) tidak ada interaksi antara kontribusi laboratorium dan sikap terhadap pemanfaatan laboratorium terhadap keterampilan berpikir kritis dan keterampilan berpikir kreatif kimia.
\end{abstract}

Kata kunci: Kontribusi Laboratorium, Sikap, Berpikir Kritis dan Kreatif

\begin{abstract}
The purpose of this research is to analyze the contribution of chemistry laboratory and student attitudes toward the utilization of chemistry laboratory toward critical and creative thinking skill. Subjects of students of class XI SMAN 66 in Cilandak, South Jakarta. Selection of sample class using random sampling technique. Analysis of research data using MANOVA. From the results of the study concluded that (1) there is influence of laboratory contribution to critical and creative thinking skill; (2) there is influence of attitude toward laboratory utilization on critical thinking and creative thinking skill; (3) there is no interaction between laboratory contributions and attitudes towards laboratory utilization of critical thinking and creative thinking skill.
\end{abstract}

Keywords: Chemistry Laboratory Contributions, Attitudes Critical, Creative Thinking

\section{PENDAHULUAN}

Keberadaan laboratorium di sekolah sangat penting dalam menunjang kegiatan belajar mengajar kimia, karena ada beberapa materi yang dalam memahaminya perlu melakukan pengamatan atau percobaan di laboratorium. Selain itu, dalam Peraturan Pemerintah Nomor 32 Tahun 2013 dijelaskan bahwa setiap satuan pendidikan wajib memiliki prasarana yang dapat menunjang proses pembelajaran yang teratur dan berkelanjutan salah satunya yaitu ruang laboratorium.

Laboratorium merupakan salah satu sumber pembelajaran kimia yang sangat diperlukan untuk memberikan pengalaman nyata pada siswa, sebagai salah satu faktor pendukung pembelajaran. Keberadaan laboratorium kimia di sekolah menengah sudah merupakan suatu keharusan pada pendidikan sains modern. Pemanfaatan laboratorium kimia yang efektif akan dapat meningkatkan keberhasilan kegiatan pembelajaran kimia (Sri, 2008). Peran laboratorium sangat penting dalam pembelajaran. Peran tersebut 
diantaranya adalah sebagai wahana untuk mengembangkan keterampilan dasar mengamati atau mengukur (menggunakan alat ukur yang sesuai) dan keterampilan keterampilan proses yang sesuai dan keterampilan - keterampilan proses lainnya, seperti mencatat data, menarik kesimpulan, berkomunikasi, bekerjasama dalam tim (Wijayanto, 2008). Maka diperlukan adanya penyediaan alat dan bahan praktikum dan kontribusi laboratorium yang baik, agar pelaksanaan pembelajaran kimia dapat berjalan secara maksimal. Selain daripada itu, sikap siswa juga turut memegang peran penting dalam berlangsungnya proses pembelajaran di laboratorium. Menurut Syah, sikap siswa adalah gejala internal yang berdimensi afektif berupa kecenderungan untuk mereaksi atau merespons (response tendency) dengan cara yang relatif tetap terhadap objek orang, barang, dan sebagainya, baik secara positif maupun negatif (Muhibbin, 2006). Sedangkan Sudjana mengatakan ada tiga komponen sikap siswa, yakni kognisi, afeksi dan konasi (Sudjana, 2002). Kognisi berkenaan dengan pengetahuan seseorang tentang objek atau stimulus yang dihadapinya, afeksi berkenaan dengan perasaan dalam menanggapi objek tersebut, sedangkan konasi berkenaan dengan kecenderungan berbuat terhadap objek tersebut. Oleh sebab itu, karena sikap selalu bermakna bila dihadapkan kepada objek tertentu, maka sikap siswa perlu digali untuk mengetahui responnya terhadap pembelajaran kimia menggunakan laboratorium.

Beberapa permasalahan yang menyebabkan siswa masih rendah dalam keterampilan berpikir kritis dan keterampilan berpikir kreatif pada mata pelajaran kimia antara lain, ilmu kimia banyak memiliki konsep-konsep yang abstrak, sehingga kimia cenderung tidak disukai dan sulit dipahami. Kurangnya pelaksanaan praktikum kimia khususnya di SMA, sikap siswa yang kurang merespon terhadap pemanfaatan laboratorium kimia, menyebabkan rendahnya keterampilan berpikir kritis dan keterampilan berpikir kreatif siswa pada mata pelajaran kimia.

Mempertimbangkan masalah-masalah tersebut, maka peneliti tertarik untuk mengangkat tema tersebut dengan mengambil judul "Kontribusi Laboratorium Kimia dan Sikap Siswa terhadap Pemanfaatan Laboratorium Terhadap Keterampilan Berpikir Kritis dan Kreatif”.

\section{TINJAUAN PUSTAKA}

Secara umum ada berbagai makna berpikir kritis, Bassham et al. (2008) menyatakan bahwa keterampilan berpikir kritis sangat berkaitan dengan alasan, yaitu mengidentifikasi, mengevaluasi, dan memberikan alasan. Ini merupakan esensi dari argumen (keterampilan berpikir kritis). Menurut Alifa (2012) materi kimia dan keterampilan berpikir kritis merupakan dua hal yang tidak dapat dipisahkan, karena materi kimia dipahami melalui berpikir kritis dan begitu juga sebaliknya berpikir kritis dilatih melalui belajar kimia. Dari pendapat beberapa ahli diatas disimpulkan bahwa keterampilan berpikir kritis kimia adalah aktifitas mental yang terjadi dalam diri siswa berawal dari kepekaan terhadap suatu permasalahan yang berkaitan dengan materi kimia yang dipecahkan secara sistematik dengan mempertimbangkan berbagai argumen kemudian menarik kesimpulan yang sesuai.

Berpikir sebagai suatu kemampuan mental seseorang yang sangat penting, salah satunya adalah berpikir kreatif. Berpikir kreatif merupakan perwujudan dari berpikir tingkat tinggi (high order thingking Menurut (Filsaime, 2008), berpikir kreatif adalah proses berpikir yang memiliki ciri-ciri kelancaran (fluency), keluwesan (flexibility), keaslian atau originalitas (originality) dan merinci atau elaborasi (elaboration). Maka dapat disimpulkan bahwa keterampilan berpikir kreatif adalah ketrampilan memunculkan ide atau gagasan dalam memecahkan masalah dengan cara yang beragam dan berbeda 
dengan yang telah ada sebelumnya namun bisa juga modifikasi dari cara yang lama dengan prinsip kebaruan.

Menurut Purwanto (2007), sikap adalah suatu cara bereaksi terhadap suatu perangsang. Dalam pengertian ini sikap merupakan kecenderungan seseorang untuk bereaksi dengan cara tertentu terhadap suatu obyek atau situasi yang dihadapisehingga sikap dapat bersifat positif dan ada pula yang bersifat negatif. Kimia merupakan salah satu mata pelajaran yang diajarkan di SMA dan merupakan suatu objek psikologi yang dapat dihubungkan dengan perasaan ataupun sikap positif dan negatif. Sikap siswa terhadap mata pelajaran kimia dapat diketahui dari cara siswa bereaksi atau memberikan respon terhadap kimia ketika kegiatan pembelajaran berlangsung, baik di dalam kelas maupun di luar kelas.

\section{METODE}

Penelitian dilaksanakan di Sekolah Menengah Atas Negeri 66, Kecamatan Cilandak, Jakarta Selatan. Populasi target dalam penelitian ini adalah seluruh siswa kelas XI SMA pada semester genap. Untuk pengambilan sampel pada penelitian ini diambil dari dua kelas secara acak. Dalam pengambilan sampel peneliti mengambil teknik sampling random sampling sehingga diperoleh 40 responden sebagai sampel.

Penelitian ini menggunakan metode penelitian kuasi eksperimen (quasi experiment) treatment dengan rancangan faktorial 2 x 2 postest only control group desain. Teknik pengumpulan data dalam penelitian ini menggunakan tes untuk melihat ketrampilan berpikir kritis dan keterampilan berpikir kreatif kimia. Data sikap siswa terhadap pemanfaatan laboratorium kimia diperoleh dengan menggunakan angket skala sikap. Pada penelitian ini akan diteliti keterampilan berpikir kritis dan keterampilan berpikir kreatif kimia dalam memecahkan masalah yang berkaitan dengan hidrolisis garam.

Uji Persyaratan analisis meliputi uji normalitas yang digunakan adalah analisis Kolmogorov Smirnov dan uji homogenitas. Hipotesis dalam penelitian diuji dengan menggunakan uji statistik manava dua-arah.

HASIL DAN PEMBAHASAN

Analisis Ketrampilan Berpiikr Kritis

Tabel 1. Hasil Perhitungan Deskriptif Keterampilan Berpikir Kritis

\begin{tabular}{ccccc}
\hline Statistik & Praktikum & $\begin{array}{c}\text { Tanpa } \\
\text { Praktikum }\end{array}$ & $\begin{array}{c}\text { Sikap } \\
\text { Positif }\end{array}$ & $\begin{array}{c}\text { Sikap } \\
\text { Negatif }\end{array}$ \\
\hline Mean & 33,25 & 26,25 & 31,85 & 27,65 \\
Median & 32 & 26 & 31 & 28 \\
Modus & 32 & 25 & 30 & 25 \\
SD & 3,275 & 2,936 & 4,793 & 3,588 \\
Min & 28 & 20 & 24 & 20 \\
Max & 39 & 30 & 39 & 32 \\
\hline
\end{tabular}




\section{Analisis Ketrampilan Berpikir Kreatif}

Tabel 2. Hasil Perhitungan Deskriptif Ketrampilan Berpikir Kreatif

\begin{tabular}{ccccc}
\hline Statistik & Praktikum & $\begin{array}{c}\text { Tanpa } \\
\text { Praktikum }\end{array}$ & $\begin{array}{c}\text { Sikap } \\
\text { Positif }\end{array}$ & $\begin{array}{c}\text { Sikap } \\
\text { Negatif }\end{array}$ \\
\hline Mean & 15,30 & 8,55 & 12,60 & 11,25 \\
Median & 16 & 9 & 13 & 9,50 \\
Modus & 16 & 9 & 17 & 9 \\
SD & 2,003 & 1,572 & 4,018 & 3,654 \\
Min & 8 & 6 & 6 & 6 \\
Max & 17 & 11 & 17 & 16 \\
\hline
\end{tabular}

Uji normalitas menunjukkan bahwa data berdistribusi normal. Sedangkan uji homogenitas menunjukkan data memiliki kesamaan varians. Pengujian hipotesis penelitian dianalisis menggunakan MANAVA dua faktor untuk mengetahui pengaruh dan interaksi antar kelompok. Tabel 3 merupakan hasil efek multivariat untuk mengetahui pengaruh variabel bebas terhadap variabel terikat secara bersama-sam

Tabel 3. Hasil Perhitungan Uji Multivariate

\begin{tabular}{|c|c|c|c|c|c|c|}
\hline Effect & & Value & $\boldsymbol{F}$ & $\begin{array}{c}\text { Hypothesis } \\
\text { df }\end{array}$ & $\begin{array}{c}\text { Error } \\
d f\end{array}$ & Sig \\
\hline \multirow[t]{4}{*}{ Intercept } & Pillai's Trace & .996 & $4627.292^{\mathrm{a}}$ & 2.000 & 35.000 & .000 \\
\hline & Wilks' Lambda & .004 & $4627.292^{\mathrm{a}}$ & 2.000 & 35.000 & .000 \\
\hline & $\begin{array}{l}\text { Hotelling's } \\
\text { Trace }\end{array}$ & 264.417 & $4627.292^{\mathrm{a}}$ & 2.000 & 35.000 & .000 \\
\hline & $\begin{array}{l}\text { Roy's Largest } \\
\text { Root }\end{array}$ & 264.417 & $4627.292^{\mathrm{a}}$ & 2.000 & 35.000 & .000 \\
\hline \multirow[t]{4}{*}{ A } & Pillai's Trace & .884 & $132.956^{\mathrm{a}}$ & 2.000 & 35.000 & .000 \\
\hline & Wilks' Lambda & .116 & $132.956^{\mathrm{a}}$ & 2.000 & 35.000 & .000 \\
\hline & $\begin{array}{l}\text { Hotelling's } \\
\text { Trace }\end{array}$ & 7.597 & $132.956^{\mathrm{a}}$ & 2.000 & 35.000 & .000 \\
\hline & $\begin{array}{l}\text { Roy's Largest } \\
\text { Root }\end{array}$ & 7.597 & $132.956^{\mathrm{a}}$ & 2.000 & 35.000 & .000 \\
\hline \multirow[t]{4}{*}{ B } & Pillai's Trace & .547 & $21.128^{\mathrm{a}}$ & 2.000 & 35.000 & .000 \\
\hline & Wilks' Lambda & .453 & $21.128^{\mathrm{a}}$ & 2.000 & 35.000 & .000 \\
\hline & $\begin{array}{l}\text { Hotelling's } \\
\text { Trace }\end{array}$ & 1.207 & $21.128^{\mathrm{a}}$ & 2.000 & 35.000 & .000 \\
\hline & $\begin{array}{l}\text { Roy's Largest } \\
\text { Root }\end{array}$ & 1.207 & $21.128^{\mathrm{a}}$ & 2.000 & 35.000 & .000 \\
\hline \multirow[t]{4}{*}{$A * \mathbf{B}$} & Pillai's Trace & .103 & $2.006^{\mathrm{a}}$ & 2.000 & 35.000 & .015 \\
\hline & Wilks' Lambda & .897 & $2.006^{\mathrm{a}}$ & 2.000 & 35.000 & .015 \\
\hline & $\begin{array}{l}\text { Hotelling's } \\
\text { Trace }\end{array}$ & .115 & $2.006^{\mathrm{a}}$ & 2.000 & 35.000 & .015 \\
\hline & $\begin{array}{l}\text { Roy's Largest } \\
\text { Root }\end{array}$ & .115 & $2.006^{\mathrm{a}}$ & 2.000 & 35.000 & 015 \\
\hline & statistic & & & & & \\
\hline & rcept $+A$ & & & & & \\
\hline
\end{tabular}


Berdasarkan hasil analisis diperoleh bahwa:

1. Terdapat perbedaan keterampilan berpikir kritis dan keterampilan berpikir kreatif secara bersama-sama antara kelompok siswa yang belajar dengan pembelajaran dengan praktikum dan pembelajaran tanpa praktikum.

2. Terdapat perbedaan keterampilan berpikir kritis dan keterampilan berpikir kreatif secara bersama-sama antara yang memiliki sikap positif terhadap pemanfaatan laboratorium kimia dengan siswa yang memiliki sikap negatif terhadap pemanfaatan laboratorium.

3. Tidak terdapat pengaruh interaksi antara keberadaan laboratorium dengan sikap siswa terhadap pemanfaatan laboratorium kimia secara bersama-sama terhadap keterampilan berpikir kritis dan keterampilan berpikir kreatif siswa.

Untuk menguji pengaruh variabel bebas terhadap masing-masing variabel terikat, dilakukan uji univariate seperti yang terdapat pada tabel 4 .

Tabel 4. Hasil Uji Univariate

\begin{tabular}{llccccc}
\hline Source & Dependent Variable & $\begin{array}{c}\text { Type III } \\
\text { Sum of } \\
\text { Squares }\end{array}$ & df & $\begin{array}{c}\text { Mean } \\
\text { Square }\end{array}$ & $\boldsymbol{F}$ & Sig \\
\hline A & $\begin{array}{l}\text { Ketrampilan Berpikir } \\
\text { Kritis Kimia }\end{array}$ & 490.000 & 1 & 490.000 & 98.547 & .000 \\
& $\begin{array}{l}\text { Ketrampilan Berpikir } \\
\text { Kreatif Kimia }\end{array}$ & 455.625 & 1 & 455.625 & 162.885 & .000 \\
B & $\begin{array}{l}\text { Ketrampilan Berpikir } \\
\text { Kritis Kimia }\end{array}$ & 176.400 & 1 & 176.400 & 35.477 & .000 \\
& $\begin{array}{l}\text { Ketrampilan Berpikir } \\
\text { Kreatif Kimia }\end{array}$ & 18.225 & 1 & 18.225 & 6.515 & .015 \\
$\begin{array}{l}\text { Ketrampilan Berpikir } \\
\text { Kritis Kimia } \\
\text { Ketrampilan Berpikir }\end{array}$ & 12.100 & 1 & 12.100 & 2.434 & .128 \\
& Kreatif Kimia & 4.225 & 1 & 4.225 & 1.510 & .227 \\
\hline
\end{tabular}

Penelitian ini bertujuan untuk mengetahui kontribusi laboratorium dan sikap siswa terhadap pemanfaatan laboratorium terhadap keterampilan berpikir kritis dan keterampilan berpikir kreatif kimia. penelitian ini dilakukan di SMA Negeri 66 pada siswa kelas XI IPA semester genap. Hasil pengujian Hipotesis membuktikan bahwa ada perbedaan keterampilan berpikir kritis dan keterampilan berpikir kreatif kimia secara bersama-sama antara kelompok siswa yang belajar dengan pembelajaran praktikum dengan kelompok siswa yang belajar dengan pembelajaran tanpa praktikum. Hal ini disebabkan oleh pembelajaran dengan praktikum memberikan pengalaman yang lebih bermakna dalam mengenal dan memahami pengetahuan kimia. Selain itu, pembelajaran dengan praktikum menuntut keaktifan siswa dalam memecahkan masalah-masalah sehingga memberikan kesempatan kepada mereka untuk mengembangkan keterampilan berpikir kritisnya melalui proses pemecahan masalah yang kompleks dalam kelompok diskusi kecil sehingga menemukan persamaan dan perbedaan, mengidentifikasi kesimpulan, merumuskan jawaban, dan menerapkan prinsip yang dapat diterima. Pembelajaran dengan praktikum lebih baik dibandingkan pembelajaran tanpa praktikum. Pembelajaran Praktikum melatih siswa untuk berpikir kreatif, dengan melaksanakan praktikum akan menstimulasi daya pikir dan kreasi siswa. 
Pembelajaran tanpa praktikum dilakukan dengan cara menyampaikan materi secara langsung dan verbal dari guru kepada siswa sehingga kental dengan teacher-centered sehingga memberikan sedikit kesempatan siswa untuk mengembangkan keterampilan berpikir kritis dan kreatif dalam memecahkan masalah. Hal ini kurang memberikan peluang bagi siswa bekerja mandiri sehingga siswa menjadi kurang aktif, kritis dan kreatif untuk mencari jawaban sendiri masalah yang dihadapinya dan lebih sering mengandalkan teman-temannya yang mempunyai keterampilan lebih, akibatnya siswa kurang memahami konsep-konsep materi yang dipelajarinya.

Uji multivariate membuktikan bahwa ada perbedaan keterampilan berpikir kritis dan keterampilan berpikir kreatif yang signifikan secara bersama-sama ditinjau dari keberadaan laboratorium yang artinya pembelajaran dengan praktikum di laboratorium memberikan pengaruh terhadap keterampilan berpikir kritis dan sekaligus terhadap keterampilan berpikir kreatif. Hasil penelitian ini sesuai dengan penelitian yang dilakukan oleh Mitarlis yang menyatakan bahwa Nilai - nilai karakter yang dapat dicapai dari kegiatan praktikum diantaranya adalah kreatif/Inovatif, rasa ingin tahu dan kritis (Mitarlis, 2012).

Selama berjalannya pembelajaran dengan praktikum di laboratorium dapat diamati bahwa sebagian besar siswa melakukan praktikum dengan semangat dan memiliki rasa ingin tahu yang besar terhadap fenomena yang muncul ketika siswa mereaksikan bahanbahan praktikum. Hal ini terlihat dengan banyaknya pertanyaan yang diajukan oleh siswa yang berkaitan dengan praktikum. Setelah pelaksanaan praktikum selesai, selanjutnya siswa bersama-sama satu kelompok mendiskusikan apa saja keterkaitan praktikum dengan materi yang disampaikan yang kemudian mereka membuat kesimpulan. Kegiatan praktikum merupakan metode yang memberikan pengaruh terhadap keberhasilan siswa dalam belajar kimia. melalui kegiatan praktikum siswa dapat mempelajari kimia melalui pengamatan proses kimia, melatih keterampilan berpikir, bersikap ilmiah, dan dapat memecahkan masalah melalui metode ilmiah. Hal ini sesuai dengan hasil penelitian Darsana, dkk (2014) yang mendapati bahwa pemanfaatan fasilitas laboratorium cukup efektif berpengaruh terhadap capaian hasil belajar peserta didik. Hal senada juga disampaikan oleh Salirawati (2009) menyatakan bahwa keberadaan laboratorium sangat penting dalam mendukung keberhasilan pembelajaran kimia agar pemahaman peserta didik terhadap materi menjadi utuh dan komprehensif.

Pada kelas yang melaksanakan pembelajaran tanpa praktikum terlihat siswa kurang semangat dan antusias. Siswa cenderung pasif, hanya menerima penjelasan materi dari guru. Keterampilan berpikir kurang berkembang. Siswa mendapat penjelasan materi dari guru kemudian mengerjakan soal-soal yang diberikan. Siswa tidak memiliki kesempatan untuk menemukan atau membuktikan konsep kimia melalui kegiatan praktikum di laboratorium. Pengetahuan yang didapat hanya berupa hapalan teori tanpa pengalaman pembelajaran yang bermakna. Sehingga ketika diberikan soal-soal yang menuntut keterampilan berpikir, siswa tidak dapat menyelesaikan dengan optimal.

Untuk Uji Univariate yakni melihat pengaruh keberadaan laboratorium terhadap masing-masing keterampilan berpikir kritis dan keterampilan berpikir kreatif kimia siswa yang dapat dilihat pada tabel 4 dengan nilai sig $<0,05$. Hal ini didukung dengan hasil analisis deskripsi data menunjukkan rata-rata skor keterampilan berpikir kritis siswa yang belajar dengan pembelajaran dengan praktikum $(33,25)$ lebih tinggi dari skor keterampilan berpikir kritis siswa yang diberi pembelajaran tanpa praktikum (26,25). Uji Hipotesis pada baris kontribusi laboratorium dan keterampilan berpikir kritis menunjukkan nilai sig < 0,05 dengan demikian keterampilan berpikir kritis dipengaruhi oleh kontribusi laboratorium. Hasil ini sesuai dengan pernyataan Alifa (2012) bahwa materi kimia dan keterampilan berpikir kritis merupakan dua hal yang tidak dapat 
dipisahkan, karena materi kimia dipahami melalui berpikir kritis dan begitu juga sebaliknya berpikir kritis dilatih melalui belajar kimia. Kegiatan praktikum di laboratorium memberikan kesempatan siswa untuk melatih keterampilan berpikir kritis seperti rasa ingin tahu, menemukan persamaan dan perbedaan, mengidentifikasi, menginterpretasi data dan menyimpulkan. Selain itu, melatih siswa untuk memikili sikap kebersamaan dan kerjasama melalui diskusi kelompok. Hal ini didukung pula oleh pendapat Pertiwi bahwa pada dasarnya praktik atau praktikum merupakan salah satu bentuk kegiatan belajar mengajar yang dimaksudkan untuk memantapkan penguasaan materi yang bersifat aplikatif (Pertiwi, 2013).

Hasil analisis deskripsi data menunjukkan rata-rata skor keterampilan berpikir kreatif siswa yang diberi pembelajaran dengan praktikum $(15,30)$ lebih tinggi dari skor keterampilan berpikir kreatif siswa yang diberi pembelajaran tanpa praktikum $(8,55)$. Uji Hipotesis pada tabel 4 baris kontribusi laboratorium dan keterampilan berpikir kreatif menunjukkan nilai sig < 0,05 dengan demikian keterampilan berpikir kreatif dipengaruhi oleh kontribusi laboratorium sehingga dapat disimpulkan keterampilan berpikir kreatif kimia dipengaruhi oleh kontribusi laboratorium.

Hasil pengujian multivariate membuktikan bahwa ada perbedaan keterampilan berpikir kritis maupun keterampilan berpikir kreatif antara siswa yang memiliki sikap positif terhadap pemanfaatan laboratorium dengan siswa yang memiliki sikap negatif terhadap pemanfaatan laboratorium. Hal tersebut didukung dengan uji univariate pada tabel 4 pada baris sikap terhadap pemanfaatan laboratorium keterampilan berpikir kritis nilai sig < 0,05 artinya terdapat perbedaan keterampilan berpikir kritis siswa antara kelompok siswa yang memiliki sikap positif terhadap pemanfaatan laboratorium dengan siswa yang memiliki sikap negatif terhadap pemanfaatan laboratorium. Deskripsi data menunjukkan bahwa rerata skor akhir keterampilan berpikir kritis siswa yang memiliki sikap positif terhadap pemanfaatan laboratorium $(31,85)$ lebih tinggi daripada rerata skor akhir keterampilan berpikir kritis siswa yang diberi yang memiliki sikap negatif terhadap pemanfaatan laboratorium $(27,65)$.

Demikian pula halnya dengan keterampilan berpikir kreatif nilai sig $<0,05$ artinya terdapat perbedaan keterampilan berpikir kreatif antara kelompok siswa yang memiliki sikap positif terhadap pemanfaatan laboratorium dengan siswa yang memiliki sikap negatif terhadap pemanfaatan laboratorium. Deskripsi data penelitian menunjukkan bahwa rerata skor akhir keterampilan berpikir kreatif siswa yang memiliki sikap positif terhadap pemanfaatan laboratorium $(12,60)$ lebih tinggi daripada rerata skor keterampilan berpikir kreatif siswa yang memiliki sikap negatif terhadap pemanfaatan laboratorium $(11,25)$. Santyasa menyatakan bahwa pembelajaran yang lebih mengutamakan pemecahan masalah, mengembangkan konsep konstruksi solusi dan algoritma lebih baikketimbang menghapal prosedur dan menggunakannya untuk memperoleh satu jawaban benar (Santyasa, 2004). Diharapkan dengan dikembangkannya keterampilan siswa dalam berpikir kreatif, maka siswa akan mampu memecahkan permasalahan yang dihadapinya dengan berbagai alternatif pemecahan masalah.

Beberapa ciri sikap positif terhadap pemanfaatan laboratorium adalah rasa antusias terhadap kegiatan praktikum, memanfaatakan alat dan bahan kimia secara optimal, tanggung jawab terhadap pemakaian alat-alat yang digunakan untuk praktikum, berparitisipas aktif pada kegiatan praktikum, mentaati prosedur penelitian. Indikatorindikator sikap tersebut jika dimiliki secara positif oleh siswa maka akan berfungsi sebagai penguat atau pendukung terlatihnya keterampilan berpikir kritis dan keterampilan berpikir kreatif kimia. Sebaliknya, jika Indikator-indikator sikap tersebut tidak dimiliki atau dimiliki secara negatif oleh siswa maka keterampilan berpikir kritis dan keterampilan berpikir kreatif kimia kurang berkembang. 
Hasil pengujian hipotesis membuktikan bahwa tidak terdapat interaksi antara kontribusi laboratorium dan sikap terhadap pemanfaatan laboratorium terhadap keterampilan berpikir kritis maupun keterampilan berpikir kreatif siswa. Sikap terhadap pemanfaatan laboratorium tidak mempengaruhi hubungan kontribusi laboratorium terhadap keterampilan berpikir kritis maupun keterampilan berpikir kreatif siswa. Tidak adanya interaksi antar kedua variabel bebas disimpulkan tidak terdapat perbedaan keterampilan berpikir kritis siswa sebagai akibat pengaruh interaksi dari implementasi kontribusi laboratorium dengan sikap siswa terhadap pemanfaatan laboratorium. Pada penelitian ini, tidak terjadi interaksi antara variabel kontribusi laboratorium dengan sikap siswa terhadap pemanfaatan laboratorium terhadap keterampilan berpikir kritis dan keterampilan berpikir kreatif kimia siswa. Variabel kontribusi laboratorium memberikan pengaruh terhadap keterampilan berpikir kritis dan keterampilan berpikir kreatif demikian pula halnya dengan variabel sikap terhadap pemanfaatan laboratorium memberikan pengaruh terhadap keterampilan berpikir kritis dan kreatif kimia namun tidak terjadi interaksi antara kedua variabel bebas tersebut.

\section{PENUTUP}

\section{Simpulan}

Dari hasil penelitian maka dapat disimpulkan sebagai berikut:

1. Terdapat perbedaan keterampilan berpikir kritis dan keterampilan berpikir kreatif secara bersama-sama antara kelompok siswa yang belajar dengan praktikum dan pembelajaran tanpa praktikum.

2. Terdapat perbedaan keterampilan berpikir kritis dan keterampilan berpikir kreatif secara bersama-sama antara yang memiliki sikap positif terhadap pemanfaatan laboratorium dengan siswa yang memiliki sikap negatif terhadap pemanfaatan laboratorium.

3. Tidak terdapat pengaruh interaksi antara kontribusi laboratorium dengan sikap siswa terhadap pemanfaatan laboratorium secara bersama-sama terhadap keterampilan berpikir kritis dan keterampilan berpikir kreatif siswa. terhadap keterampilan berpikir kritis dan keterampilan berpikir kreatif kimia siswa.

\section{Saran}

1. Hendaknya dalam mengajarkan kimia, guru diharapkan dapat merancang dan mengembangkan pembelajaran yang dapat melatihketrampilan berpikir kritis dan ketrampilan berpikir kreatif siswa yaitu dengan pembelajaran dengan praktikum di laboratorium.

2. Kepada peneliti dan pemerhati pendidikan khususnya bidang pendidikan kimia,perlu diadakan penelitian lanjutan untuk sampel yang lebih besar dan variable penelitian yang lebih beragam.

\section{DAFTAR PUSTAKA}

Alifa Noor Rahma. 2012. Pengembangan perangkat pembelajaran model inkuiri berpendekatan SETS materi kelarutan dan hasilkali kelarutan untuk menumbuhkan ketrampilan berpikir kritis dan empati siswa terhadap lingkungan. Journal of Educational Research and Evaluation 1 (2) 2012. http://journal.unnes.ac.id/sju/index.php/jere)

Bassham, dkk. 2008. Critical thinking: A student's introduction. 3rd Edition. New York: McGraw-Hill Company, Inc.

Darsana, I Wayan., Sadia, I Wayan., Tika, I Nyoman. 2014. Analisis Standar Kebutuhan Laboratorium Kimia Dalam Implementasi Kurikulum 2013 Pada 
SMA Negeri di Kabupaten Bangli. e-journal Program Pascasarjana Universitas Pendidikan Ganesha Program Studi IPA Vol. 4.

Filsaime, D. K. 2008. Menguak Rahasia Berpikir Kritis dan Kreatif. Jakarta. Prestasi Pustaka.

Purwanto, N. 2007. Psikologi Pendidikan. Bandung: PT Remaja Rosdakarya.

Mitarlis. 2012. Peranan Kegiatan Praktikum Kimia Dasar I Materi Pemisahan Campuran dalam rangka Pencapaian Nilai - nilai Karakter Bagi Mahasiswa Kimia UNESA dengan Model Terintegrasi. Prosiding Seminar Nasional Kimia UNESA, 63 - 72, Surabaya.

Rahmiyati, Sri. 2008. The effectiveness of laboratory use in madrasaah aliyah in Yogyakarta. Jurnal Penelitian dan Evaluasi Pendidikan, X1(1), 88-100.

RI, Pertiwi. 2013. Persepsi mahasiswa tentang penyelenggaraan praktikum pada pendidikan tinggi terbuka jarak jauh. Jurnal Pendidikan Terbuka dan Jarak Jauh 4(1) , 45-56.

Salirawati, Das. 2009. Manajemen Laboratorium Kimia/IPA. Makalah disajikan dalam Kegiatan Pembinaan MGMP bagi Guru SMA dan SMK Angkatan III se Kabupaten Sleman di Dinas Pendidikan Kabupaten Sleman.

Santyasa, I.W. 2004. Model Problem Solving dan Reasoning Sebagai Alternatif

Pembelajaran Inovatif. Makalah disampaikan dalam Konvensi Nasional Pendidikan Indonesia V, Surabaya, 5 - 9 Oktober 2014.

Sudjana, N. 2002. Penilaian Hasil Proses Belajar Mengajar. Bandung: Remaja Rosda Karya.

Syah, M. 2006. Psikologi Belajar. Jakarta: PT. Raja Grafindo Persada.

Wijayanto. 2008. Menyiapkan Guru Sains Mengembangkan Kompetensi Laboratorium. Semarang: UNNES Press. 